\title{
POTENSI EKSTRAK ETANOL SELEDRI (Apium graveolens) UNTUK MASKULINISASI IKAN CUPANG (Betta sp)
}

\author{
Potential of Celery (Apium Graveolens) Ethanol Extract for Masculinization of \\ Betta Fish (Betta sp)
}

\author{
Awaludin ${ }^{1 *}$, Diana Maulianawati ${ }^{1}$, Muhammad Adriansyah ${ }^{1}$ \\ ${ }^{1}$ Akuakultur, FPIK Universitas Borneo Tarakan, Jl. Amal Lama, No.01, Tarakan \\ *Korespondensi: awaludin@borneo.ac.id
}

\begin{abstract}
ABSTRAK
Ikan cupang salah satu ikan hias primadona karena memiliki nilai ekonomis yang tinggi. Ikan cupang yang bernilai ekonomis yaitu ikan cupang jantan, karena memiliki bentuk yang indah. Untuk meningkatkan produksi ikan jantan, langkah yang dapat dilakukan dengan cara maskulinisasi. Penelitian ini bertujuan untuk mengetahui pengaruh ekstrak seledri sebagai agen steroid like yang berperan dalam proses maskulinisasi terhadap persentase ikan cupang jantan. Penelitian ini menggunakan Rancangan Acak Lengkap (RAL) dengan 6 perlakuan dan 3 ulangan. Perlakuan dalam penelitian ini adalah larva ikan cupang umur 7 hari yang direndam dalam media ekstrak seledri dengan konsentrasi berbeda selama 8 jam. Perlakuannya adalah penambahan ekstrak seledri sebanyak $5 \mathrm{mg} / \mathrm{L}$ (P1), $10 \mathrm{mg} / \mathrm{L}$ (P2), $20 \mathrm{mg} / \mathrm{L}$ (P3), $40 \mathrm{mg} / \mathrm{L}$ (P4), $80 \mathrm{mg} / \mathrm{L}$ (P5) dan tanpa penambahan ekstrak seledri sebagai kontrol (P0). Pengujian Pengujian fitokimia menunjukkan ekstrak etanol seledri mengandung steroid, flavonoid, tannin dan fenol. Hasil penelitian menunjukkan bahwa penambahan ekstrak seledri dengan konsentrasi yang berbeda, berpengaruh secara signifikan pada persentase ikan cupang jantan, namun tidak berpengaruh terhadap tingkat kelangsungan hidup.
\end{abstract}

Kata Kunci: Ekstrak Etanol Seledri; Ikan cupang; Maskulinisasi; Perendaman; Sex Reversal

\begin{abstract}
Betta fish is one of the excellent ornamental fish because it has high economic value. Betta fish that have economic value are male betta fish because it has a beautiful shape. To increase male fish production, steps can be done by masculinization. This study aims to determine the effect of celery extract as a steroid-like agent that plays a role in the process of masculinization of the percentage of male betta fish. This study uses a completely randomized design (CRD) with 6 treatments and 3 replications. The treatment in this study was 7-day-old betta fish larvae soaked in celery extract media with different concentrations for 8 hours. The treatment is the addition of celery extract as much as 5 $\mathrm{mg} / \mathrm{L}$ (P1), $10 \mathrm{mg} / \mathrm{L}$ (P2), $20 \mathrm{mg} / \mathrm{L}$ (P3), $40 \mathrm{mg} / \mathrm{L}$ (P4), $80 \mathrm{mg} / \mathrm{L}$ (P5) and without the addition of celery extract as a control (P0). Testing Phytochemical testing shows celery ethanol extract containing steroids, flavonoids, tannins, and phenols. The results showed that the addition of celery extract with different concentrations significantly affected the percentage of male betta fish, but did not affect the survival rate.
\end{abstract}

Keywords : Betta fish; Celery Ethanol Extract; Immersion; Masculinization; Reversal Sex 


\section{PENDAHULUAN}

Produksi ikan hias 2019 mencapai 33,89 juta ekor atau sekitar $66,78 \%$ dari jumlah target, sehingga hal ini harus terus ditingkatkan jumlah produksi ikan hias (KKP, 2019). Salah satu ikan hias yang diproduksi adalah ikan cupang (Betta sp). Ikan cupang (Betta sp) adalah ikan air tawar yang berasal dari daerah tropis dan banyak ditemukan di perairan Asia Tenggara, termasuk Indonesia dengan beragam jenisnya. Ikan ini hidup di alam bebas dengan habitatnya yang berada di rawa-rawa, danau dan sungai dengan arus yang tenang. Ikan cupang merupakan ikan air tawar yang menjadi primadona karena nilai ekonomis tinggi dan banyak terdapat di pasaran dan menjadi salah satu komoditas ekspor Indonesia

Ikan cupang memiliki keinda-han bentuk sirip dan warna, sehingga kerapkali diikutkan dalam ajang kontes maupun pameran ikan hias. Biasanya penampakan dari warna dan keindahan bentuk sirip ikan cupang terdapat pada ikan jantannya. Ikan cupang jantan memiliki warna mencolok, sirip panjang dan tubuh yang lebih kecil daripada betinanya. Karena keindahan bentuk sirip dan warnanya inilah ikan cupang jantan memiliki harga jual yang lebih tinggi dibandingkan dengan ikan cupang betina. Sehingga diperlukan upaya untuk meningkatkan jumlah produksi ikan jantan melalui proses maskulinisasi untuk mengarhakan ikan menjadi jantan.

Metode maskulinisasi telah banyak diterapkan dengan berbagai cara seperti penggunaan hormon dan perubahan lingkungan. Pemberian hormon androgen pada fase diferensiasi gonad pada ikan mampu meningkatkan proses maskulinisasi. Dengan pemberian hormon ini mampu memicu ransangan pada sistem syaraf dan memacu pelepasan hormon gonadotropin untuk pembentukan gonad jantan (Arfah et al., 2013). Penggunaan hormone dalam proses maskulinisasi telah banyak dilakukan untuk meningkatkan ikan menjadi jantan. Upaya ini telah banyak dilakukan pada beberapa ikan dengan menggunakan bahan yang berbeda, salah satunya hormon $17 \alpha$ metiltestoteron, tetapi hormon sintetis $17 \alpha$-mt termasuk dalam klasifikasi obat keras yang berarti bahwa peredaran dan pemanfaatannya menjadi semakin dibatasi terkait dengan dampak negatif yang dapat ditimbulkan, baik pada ikan, manusia maupun lingkungan. Homllin et al (2009) melaporkan bahwa hormone $17 \alpha$-metiltestosteron telah dilarang dalam kegiatan akuakultur karena sulit terdegradasi secara alami sehingga berpotensi dapat merusak lingkungan. Sehingga diperlukan dicari bahan alam pengganti hormone sistetik, untuk proses maskulinisasi.

Bahan alam yang dapat digunakan dalam proses maskulinisasi ikan Betta splendens yaitu ekstrak Pimpinella alpine mengandung bahan aktif stigmasterol yang bersifat afrodi-siak (Afrah $e t$ al., 2013) dan tumbuhan Lunasia amara yang bersifat afrodisiak yang mampu meningkatkan libido rusa Timur jantan, sehingga berpeluang untuk digunakan dalam maskulinisasi ikan (Zumrotun et al., 2006). Selain tumbuhan tersebut yang diduga mampu memberikan maskulinisasi yaitu seledri (Apium graveolens).

Seledri mengandung flavonoid, fenol, saponin, kumarin, dan steroid atau triterpenoid. Samejo et al., (2013) mengemukakan bahwa steroid merupakan terpenoid lipid yang dikenal dengan empat cincin kerangka dasar karbon yang menyatu. Struktur senyawanya pun cukup beragam. Perbedaan tersebut disebabkan karena adanya gugus fungsi teroksidasi yang terikat pada cincin dan terjadinya oksidasi cincin karbonya. Putra (2011), menyatakan bahwa proses maskulinisasi menggunakan bahan alami yang memiliki senyawa steroid yang sama dengan ginseng yaitu purwoceng (Pimpinella alpina) dengan dosis $20 \mathrm{mg} / \mathrm{L}$ dan lama perendaman selama 8 jam menghasilkan ikan nila jantan sebesar $73.3 \%$. Selain purwoceng, bahan alami lainnya yakni akar ginseng yang digunakan oleh 
Ferdian et al., (2017) untuk maskulinisasi dengan dosis $3 \mathrm{mg} / \mathrm{L}$ dan lama perendaman larva selama 8 jam mampu menghasilkan ikan cupang jantan sebesar 95,05\%. Berdasarkan hal tersebut peneliti bermaksud menggunakan tumbuhan seledri (A. graviolens) yang mengandung hormon steroid yang dapat memacu pembalikan arah jenis kelamin pada ikan cupang, maskulinisasi menggunakan ekstrak tumbuhan seledri diharapkan juga dapat diterapkan sehingga dapat meningkatkan persentase ikan jantan yang lebih unggul.

\section{METODE PENELITIAN}

\section{Alat dan Bahan}

Alat yang digunakan dalam penelitian antara lain beaker glass, evaporator, akuarium volume 30 liter dan Erlenmeyer. Bahan yang digunakan antara lain larva ikan cupang (Betta sp), daun seledri, aquades, ethanol $70 \%$.

\section{Ekstraksi Seledri (A. Graveolens)}

Ekstraksi dengan metode maserasi. Daun seledri yang digunakan terlebih dahulu dikeringkan, kemudian blender hingga halus. Ekstraksi dengan pelarut alkohol $70 \%$ dengan perbandingan (3:1) alkohol (3 liter) dan simplisia (1 kg) kemudian direndam selama $3 \times 24$ jam pada suhu kamar. Cairan ekstrak yang telah dimaserasi kemudian disaring dan di evaporasi. (Awaludin dan Ridwan, 2016).

\section{Uji Fitokimia}

Pengujian fitokimia dilakukan dengan metode tabung dengan cara mengambil ekstrak ethanol tumbuhan seledri, kemudian ditambahkan reagen sesuai dengan senyawa yang akan diidentifikasi yakni alkaloid, flavonoid dan steroid (Harborne, 1996). Uji Fitokimia meliputi uji alkaloid, uji steroid/triterpenoid, flavonoid, tanin, saponin dan fenol. Prosedur pengujiannya adalah sebagai berikut :

\section{a. Uji Alkaloid}

Sampel 0,01 gram dilarutkan dalam beberapa tetes asam sulfat $2 \mathrm{~N}$. Pengujian menggunakan 3 pereaksi alkaloid yaitu pereaksi Dragendorff, pereaksi Mayer dan pereaksi Wagner.

\section{b. Steroid/Triterpenoid}

Sampel 0,01 gram dilarutkan dalam $2 \mathrm{~mL}$ kloroform dalam tabung reaksi yang kering, setelah itu ditambahkan 10 tetes anhidra asetat dan 3 tetes asam sulfat pekat. Reaksi positif ditunjukkan dengan terbentuknya larutan berwarna merah untuk pertama kali kemudian berubah menjadi biru dan hijau.

\section{c. Flavonoid}

Sampel 0,01 gram ditambahkan $0,1 \mathrm{mg}$ serbuk magnesium dan $0,4 \mathrm{~mL}$ amil alkohol (campuran asam klorida $37 \%$ dan etanol $95 \%$ dengan volume yang sama) dan $4 \mathrm{~mL}$ alcohol kemudian dicampur dikocok. Adanya flavonoid ditunjukkan dengan terbentuknya warna merah, kuning atau jingga pada lapisan amil alkohol.

\section{d. Saponin (Uji Busa)}

Saponin dapat dideteksi dengan uji busa dalam air panas. Busa yang stabil selama 30 menit dan tidak hilang pada penambahan 1 tetes HCL $2 \mathrm{~N}$ menunjukkan adanya saponin.

\section{e. Fenol (Pereaksi $\mathrm{FeCl}_{3}$ )}

Sampel 0,01 gram diekstrak dengan $20 \mathrm{~mL}$ etanol $70 \%$. Larutan yang dihasilkan diambil sebanyak $1 \mathrm{~mL}$ kemudian ditambahkan 2 tetes larutan $\mathrm{FeCl}_{3} 5 \%$. Adanya senyawa fenol dalam bahan ditunjukkan dengan terbentuknya warna hijau atau hijau biru.

\section{Uji BSLT}

Pengujian BSLT dilakukan dengan pembuatan larutan uji. Larutan uji kemudian dibuat dengan konsentrasi 1000, 500, 300, 100, 50, 10, dan $0 \mathrm{mg} / \mathrm{L}$, 
masing-masing dipipet sebanyak $5 \mathrm{~mL}$ dimasukkan ke dalam tabung reaksi dan ditambahkan 20 ekor larva artemia yang telah berumur 1 hari. Setiap konsentrasi dilakukan 3 kali pengulangan dan dibandingkan dengan kontrol. Pengamatan I dilakukan selama 6 jam dengan selang waktu 1 jam. Selanjutnya pengamatan II dilakukan pada 12, 18 dan 24 jam. Jumlah larva artemia yang mati dihitung tiap 6, 12, 18 dan 24 jam.

\section{Pemijahan Induk Ikan Cupang}

Pemijahan ikan cupang memodifikasi dari penelitian Purwati et al (2004). Pemijahan ikan cupang dilakukan dengan cara memasukkan induk jantan terlebih dahulu ke dalam wadah pemijahan, selanjutnya induk betina yang ditempatkan pada gelas plastik transparan ke dalam wadah pemijahan. Tujuan dari penempatan induk betina plastik di dalam gelas plastik transparan yaitu untuk merangsang induk jantan agar segera membuat sarang berupa gelembunggelembung busa sebelum terjadi proses pemijahan, selain itu untuk mengurangi kontak fisik (serangan) dari induk jantan yang dapat menyebabkan induk betina mengalami kerusakan pada bagian tubuh, terutama pada bagian sirip selama proses pemijahan. Penempatan induk betina di dalam gelas plastik transparan dilakukan selama kurang lebih 12 jam hingga induk jantan selesai membuat sarang, sehingga ketika induk betina dilepaskan dari gelas plastik transparan kedalam wadah pemijahan, proses pemijahan akan segera berlangsung. Telur hasil proses pemijahan yang telah selesai dibuahi akan menempel pada sarang di bagian tepi wadah pemijahan kemudian kedua induk dikeluarkan dari wadah pemijahan.

\section{Persiapan Wadah Pemeliharaan}

Persiapan wadah pemeliharaan dimulai dengan pembersihan selanjutnya dilakukan pemasangan label perlakuan sesuai rancangan penelitian dan diisi air dengan volume $30 \mathrm{~L}$.

\section{Hewan Uji}

Hewan uji yang digunakan adalah larva ikan cupang yang berumur 7 hari yang diperoleh dari pemijahan alami.

\section{Perendaman Larva}

Proses perendaman larva dalam ekstrak seledri disesuaikan dengan perlakuan. Larva yang digunakan berumur 7 hari. Wadah perendaman menggunakan akuarium soliter bervolume $2 \mathrm{~L}$ pada setiap masing-masing wadah diisi sebanyak 20 ekor larva dalam 1 L ektrak. Lama waktu perendaman 8 jam dan selama perendaman diamati kelangsungan hidupnya. Setelah 8 jam, larva dipindahkan pada wadah pemeliharaan. Metode penelitian yang digunakan dalam penelitian ini adalah metode eksperimental (percobaan). Rancangan yang digunakan pada penelitian ini adalah rancangan acak lengkap (RAL) dengan 6 perlakuan dan 3 kali ulangan. Perlakuan yang digunakan adalah perendaman larva ikan cupang yang berumur 7 hari dengan ekstrak seledri dengan lama perendaman 8 jam (Ferdian et al., 2017). Pada saat perendaman wadah disiapkan berupa sterofoam soliter berjumlah 18 buah dengan volume 2 liter yang kemudian diisi air dengan ekstrak sebanyak 1 liter setelahnya dimasukkan beruayak ikan cupang sebanyak 20 ekor perakuarium kemudian diamati sintasan selama perendaman $8 \mathrm{jam}$. Adapun dosis yang digunakan adalah sebagai berikut :

$\mathrm{P} 0=$ Kontrol (tanpa ekstrak seledri)

$\mathrm{P} 1=$ Konsentrasi ekstrak seledri $5 \mathrm{mg} / \mathrm{L}$ (Ferdian et al., 2017)

P2 = Konsentrasi ekstrak seledri 10 $\mathrm{mg} / \mathrm{L}$

P3 = Konsentrasi ekstrak seledri 20 $\mathrm{mg} / \mathrm{L}$

P4 = Konsentrasi ekstrak seledri 40 $\mathrm{mg} / \mathrm{L}$

$\mathrm{P}_{5}=$ Konsentrasi ekstrak seledri 80 $\mathrm{mg} / \mathrm{L}$ 


\section{Pemeliharaan Larva}

Larva yang telah direndam, dipelihara di dalam box steroform dengan volume 30 liter selama 60 hari. Pada waktu pemeliharaan, larva diberi pakan alami berupa Infusoria, Daphnia sp, dan Jentik Nyamuk secara ad libitum. Pakan alami Infusoria diberikan untuk larva setelah kuning telur habis yaitu pada saat larva berumur 4 hari. Pada hari keempat, larva mulai diberi pakan alami Infusoria (4-15 hari), Daphnia sp (10-30 hari) dan Jentik Nyamuk (25-60 hari). Pemberian pakan dilakukan secara ad libitum (Sugandy, 2001).

\section{Identifikasi Kelamin Ikan}

Identifikasi kelamin dilakukan dengan pengamatan secara morfologi karena tidak perlu membunuh hewan uji untuk melakukan pengamatan terhadap organ reproduksi. Cara ini ideal untuk ikan-ikan yang memiliki dimorfisme yang jelas antara jantan dengan betinanya. Beberapa jenis ikan hias seperti guppy, rainbow, cupang dan kongo mudah dibedakan antara jantan dengan betina berdasarkan morfologi tubuhnya (Zairin, 2002).

\section{Parameter Penelitian}

\section{Persentase Ikan Cupang Jantan}

Pengukuran ikan cupang jantan dilakukan dengan membandingkan jumlah ikan jantan dengan jumlah ikan yang hidup pada akhir pemeliharaan. Rumus yang digunakan untuk menghitung persentase ikan jantan menurut Zairin (2002) sebagai berikut :

$$
I=\frac{\text { Jumlah Ikan Jantan }}{\text { Jumlah ikan hidup akhir pemeliharaan }} \times 100 \%
$$

\section{Survival Rate Pasca Pemeliharaan}

Kelangsungan hidup merupakan persentase jumlah ikan yang hidup pada akhir penelitian setelah dibagi jumlah ikan pada awal penelitian. Menurut Priyono et al (2013), kelangsungan hidup (survival rate) dapat diketahui dengan menggunakan rumus sebagai berikut :

$$
S R=\frac{N t}{N o} \times 100 \%
$$

Dimana:

$\mathrm{SR}=$ Survival rate $(\%)$

$\mathrm{Nt}=$ Jumlah ikan yang hidup pada akhir pengamatan (ekor)

No $=$ Jumlah ikan awal (ekor)

\section{Kualitas Air}

Kualitas air yang diukur dalam penelitian ini adalah suhu, derajat keasaman $(\mathrm{pH})$ dan oksigen terlarut (Disolved Oxygen). Pengukuran parameter tersebut dilakukan pada awal pemeliharaan dan akhir pemelihraan kemudian dibuat rentang nilai nya masing-masing parameter.

\section{Analisis Data}

Data-data yang diperoleh selama penelitian kemudian dianalisis secara statistik dengan menggunakan analisis varian (One-Way ANOVA) untuk mengetahui perbedaan antara perlakuan dan kontrol untuk mengetahui signifikansi perbedaan rata-rata dengan tingkat kepercayaan $95 \%$. Program yang digunakan untuk menganalisis data tersebut menggunakan software SPSS Versi 21 dan dilakukan uji lanjut Benda Nyata Terkecil apabila hasil menyatakan berbeda nyata.

\section{HASIL DAN PEMBAHASAN}

\section{Uji Fitokimia Ekstrak Seledri}

Uji fitokimia digunakan untuk mendeteksi senyawa tumbuhan berdasarkan golongannya sebagai informasi awal dalam mengetahui golongan senyawa kimia yang mempunyai aktivitas biologi dari suatu tanaman. Uji fitokimia dilakukan untuk mengetahui kandungan senyawa aktif yang terdapat pada tumbuhan seledri. Uji Fitokimia meliputi uji alkaloid, uji steroid, flavonoid, tanin, saponin dan fenol. Hasil uji fitokimia dapat dilihat pada Tabel 1. 
Uji alkaloid pada ekstrak seledri ini dilakukan dengan menggunakan pereaksi Meyer. Pada uji alkaloid dengan pereaksi Meyer, indikator positif dari pengujiannya adalah terbentuknya endapan putih setelah ditambahkan pereaksi. Hasil uji alkaloid menunjukkan bahwa tidak terbentuk endapan putih pada ekstrak seledri (Gambar 1A). Hal ini menunjukkan bahwa sampel tersebut negatif mengandung alkaloid. Pada uji steroid, reaksi positif ditunjukkan dengan terbentuknya larutan berwarna merah untuk pertama kali kemudian berubah menjadi biru dan hijau. Senyawa fenol dalam bahan ditunjukkan dengan terbentuknya warna hijau atau hijau biru. Hasil pengujian senyawa fenol dengan indicator berwarna hijau kecoklatan menandakan positif senyawa fenol (Gambar 1B). Adanya flavonoid ditunjukkan dengan terbentuknya warna merah, kuning atau jingga pada lapisan amil alkohol. Terbentuknya warna kuning kehijauan yang menunjukkan adanya senyawa flavonoid pada ekstrak seledri (Gambar 1C). Terbentuknya warna hijau pekat yang menunjukkan adanya senyawa steroid pada ekstrak tumbuhan seledri (Gambar 1D). Uji tanin menunjukkan terbentuknya warna hijau kehitaman pada sampel. Indikator positif dari uji tanin adalah terbentuknya warna biru tua atau hijau kehitaman pada sampel. Pada Gambar 1E- menunjukkan bahwa ekstrak seledri positif mengandung senyawa tannin. Saponin dapat dideteksi dengan uji busa dalam air panas. Busa yang stabil selama 30 menit dan tidak hilang pada penambahan 1 tetes HCL $2 \mathrm{~N}$ menunjukkan adanya saponin, dari hasil pengujian (Gambar 1F) diketahui bahwa tidak terbentuknya lapisan busa pada dengan demikian dapat diketahui bahwa ekstrak seledri negatif mengandung senyawa saponin. Martha dan Zummah (2018) melaporkan bahwa ekstrak seledri menunjukkan positif adanya flavonoid dan negatif adanya alkaloid dan saponin.

Tabel 1. Hasil Uji Fitokimia Ekstrak Seledri

\begin{tabular}{llc}
\hline \multicolumn{1}{c}{ Senyawa Aktif } & \multicolumn{1}{c}{ Warna } & Hasil \\
\hline Alkoloid & Kuning Kecoklatan & - \\
Steroid & Hijau Pekat & +++ \\
Flavonoid & Kuning kehijauan & + \\
Tanin & Kuning Kehijauan & + \\
Fenol & Hijau Kecoklatan & ++ \\
Saponin & Tidak Ada Busa & - \\
\hline
\end{tabular}

Keterangan : $(+)=$ Menunjukkan Positif, $(++)=$ Konsentrasi Pekat, $(+++)=$ Konsentrasi Sangat Pekat, $(-)=$ Menunjukkan Negatif 

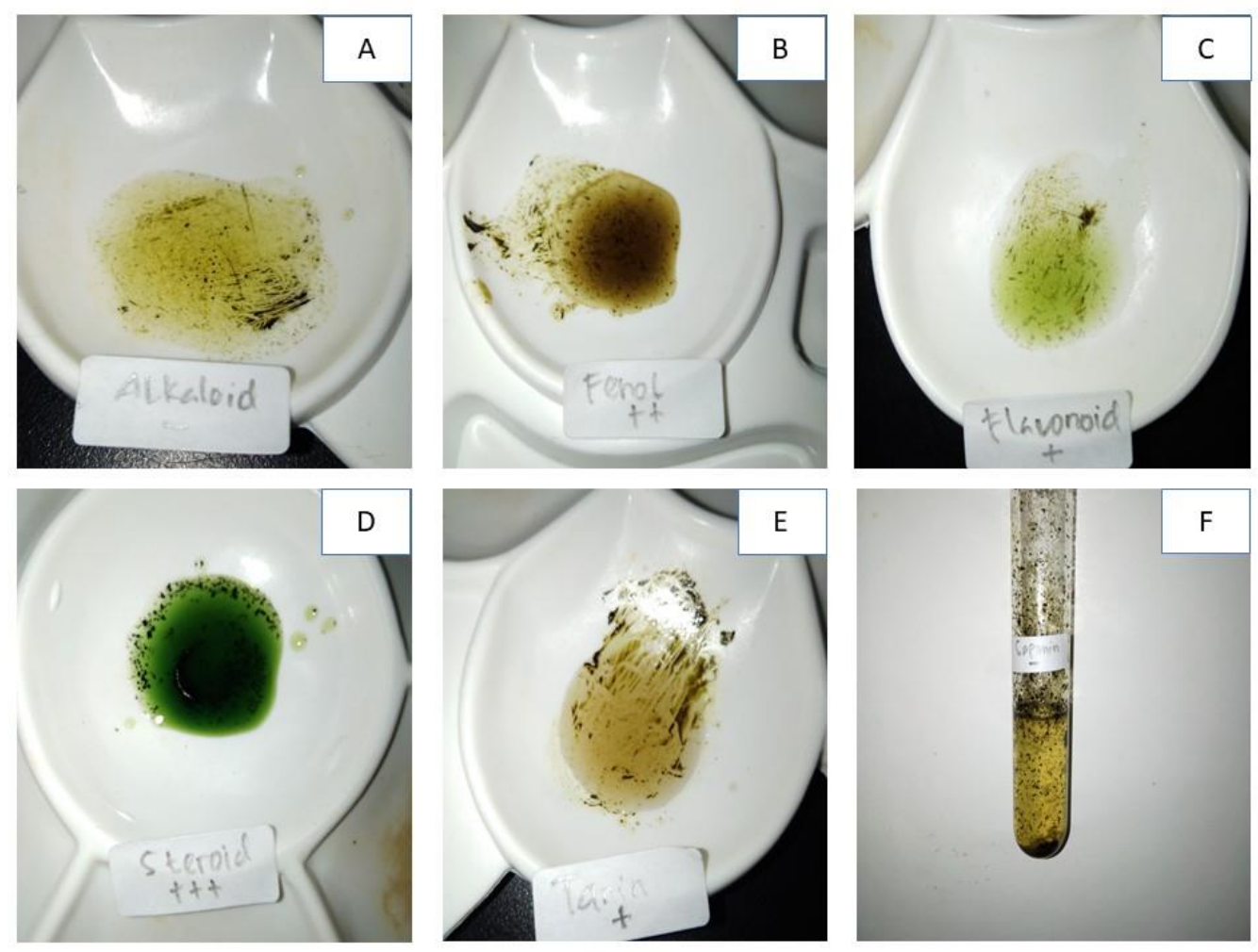

Gambar 1. Hasil Uji Fitokimia Ekstrak Seledri. Keterangan: A: Uji Alkaloid, B: Uji Fenol, C: Uji Flavonoid, D: Uji Steroid, E: Tanin, F: Saponin

\section{Uji BSLT}

Metode uji toksisitas larva udang Brine Shrimp Lethality Test (BSLT) menggunakan Artemia salina merupakan metode bioassay konvensional yang umum digunakan untuk menguji komponen aktif tumbuhan. Penggunaan BSLT sebagai uji bioaktivitas memiliki beberapa keuntungan yaitu mudah, cepat, murah, sederhana (tidak memerlukan keterampilan dan peralatan khusus), dan hasilnya dapat dipercaya (Meyer et al. 1982). Dalam uji ini diamati tingkat mortalitas larva udang $A$. salina yang disebabkan oleh ekstrak tumbuhan dengan konsentrasi tertentu. Senyawa tumbuhan yang aktif akan menghasilkan tingkat mortalitas yang tinggi. Data besarnya mortalitas yang diperoleh akan diolah untuk mendapatkan $\mathrm{LC}_{50}$ (Lethal Concentration 50\%) pada tingkat kepercayaan 95\% dengan menggunakan Probit Analysis Method sebagai perbandingan potensi signifikan secara statistik. $\mathrm{LC}_{50}$ merupakan besarnya konsentrasi $(\mu \mathrm{g} / \mathrm{mL})$ ekstrak yang diuji untuk dapat mematikan $50 \%$ dari hewan uji. Uji BSLT dilakukan untuk mengatahui tingkat toksisitias dari suatu senyawa, hasil uji toksisitas dari ekstrak seledri dapat dilihat pada Tabel 2.

Pada Tabel 2 dapat diketahui bahwa tingkat kematian tertinggi berada pada konsentrasi 1000 ppm dengan jumlah larva yang mati sebanyak 20 ekor dengan persentase kematian sebesar $100 \%$ pada akhir pengamatan, dapat disimpulkan bahwa semakin tinggi konsentrasi ekstrak menghasilkan jumlah kematian larva yang semakin tinggi pula. Nilai probit ektrak etanol seledri dengan menggunakan larva $A$. salina sebesar $275, \quad 368 \mathrm{mg} / \mathrm{l}$, konsentrasi ini menunjukkan ekstrak seledri termaksud dalam golongan toksik moderat (Carballo et al., 2002). 
Tabel 2. Hasil Uji Toksisitas Ekstrak Seledri

\begin{tabular}{ccc}
\hline Konsentrasi (mg/l) & Larva yang mati & Nilai probit $(\mathbf{m g} / \mathbf{l})$ \\
\hline 0 & 0 & \\
10 & 1 & \\
50 & 5 & \\
100 & 5 & \\
300 & 8 & \\
500 & 40 & \\
1000 & 20 & \\
\hline
\end{tabular}

\section{Persentase Ikan Cupang Jantan}

Berdasarkan dari hasil penelitian ini, dapat dilihat pada Gambar 2 bahwa perendaman larva ikan cupang dalam ekstrak seledri dengan dosis masingmasing $0,5,10,20,40 \mathrm{dan} 80 \mathrm{mg} / \mathrm{L}$ berpengaruh terhadap persentase ikan cupang jantan. Berdasarkan analisis sidik ragam dosis pemberian ekstrak seledri pada perendaman larva ikan cupang berpengaruh nyata terhadap persentase ikan cupang jantan. Pada setiap perlakuan persentase ikan jantan masing-masing adalah Kontrol $(45,00 \pm 5,00 \%)$, P1 $(68,33 \pm 7,64 \%)$, P2 $(73,33 \pm 10,41 \%)$, P3 $(56,67 \pm 5,77 \&)$, P4 $(50,00 \pm 5,00 \%)$ dan P5 $(43,33 \pm 5,77$ $\%)$ dengan persentase ikan cupang jantan tertinggi diperoleh pada perlakuan P2 yaitu sebesar $(73,33 \pm 10,41$ $\%$ ), sedangkan persentase ikan cupang jantan terendah diperoleh pada perlakuan P5 yaitu sebesar $(43,33 \pm 5,77$ $\%)$. Berdasarkan analisis sidik ragam dosis pemberian ekstrak seledri pada perendaman larva ikan cupang berpengaruh nyata terhadap persentase ikan cupang jantan.

Berdasarkan Gambar 2 menunjukkan bahwa terjadi peningkatan persentase ikan cupang jantan seiring dengan penambahan dosis ekstrak seledri sampai $10 \mathrm{mg} / \mathrm{L}$. namun terjadi penururnan persentase ikan cupang jantan pada penambahan dosis ekstrak seledri sebesar $40 \mathrm{mg} / \mathrm{L}$. Zairin (2002), yang menyatakan bahwa terdapat kecenderungan pada pemberian hormon dan dosis yang digunakan, yakni pemberian dosis yang terlalu rendah menyebabkan ikan menjadi steril, abnormalitas dan apabila dosis yang digunakan terlalu tinggi dapat menyebabkan kematian pada ikan. Dari hasil uji fitokimia tumbuhan seledri peneliti juga menunjukkan hasil positif dari senyawa steroid yang menjadi kunci dalam pembalikan arah kelamin pada masa diferensiasi kelamin ikan cupang.

Piferrer dan Donaldson (1989) bahwa dosis yang tinggi dan waktu perendaman yang terlalu lama juga akan bersifat paradoksial yaitu hasil yang diperoleh bukanlah peningkatan jumlah ikan jantan akan tetapi akan meningkatkan jumlah ikan betina. Berdasarkan hasil uji BNT, perlakuan P2 berbeda nyata dibandingkan dengan semua perlakuan. Perbedaan morfologi ikan cupang jantan dan betina setelah pemberian ekstrak seledri dapat dilihat pada Gambar 3.

Membedakan ikan cupang jantan dan betina sangatlah mudah karena dapat dilihat langsung dari ciri sekunder atau morfologinya saja, umumnya untuk membedakan antara ikan cupang jantan dan betina dapat dilihat dari warnanya, ikan cupang jantan berwarna lebih cerah dari ikan cupang betina. Hasil pengamatan secara sekunder dari ikan cupang hasil maskulinisasi ekstrak seledri diketahui ciri-ciri morfologi yaitu ikan cupang jantan memiliki ukuran tubuh yang lebih kecil, sirip anal lebih panjang dan bentuk ekor yang lebih besar serta warna yang lebih cerah, sedangkan morfologi ikan cupang betina yaitu ukuran tubuh yang lebih besar, sirip anal yang pendek dan bentuk ekor yang relative kecil dari ikan cupang jantannya serta warna yang kurang menarik dari ikan cupang jantan. 


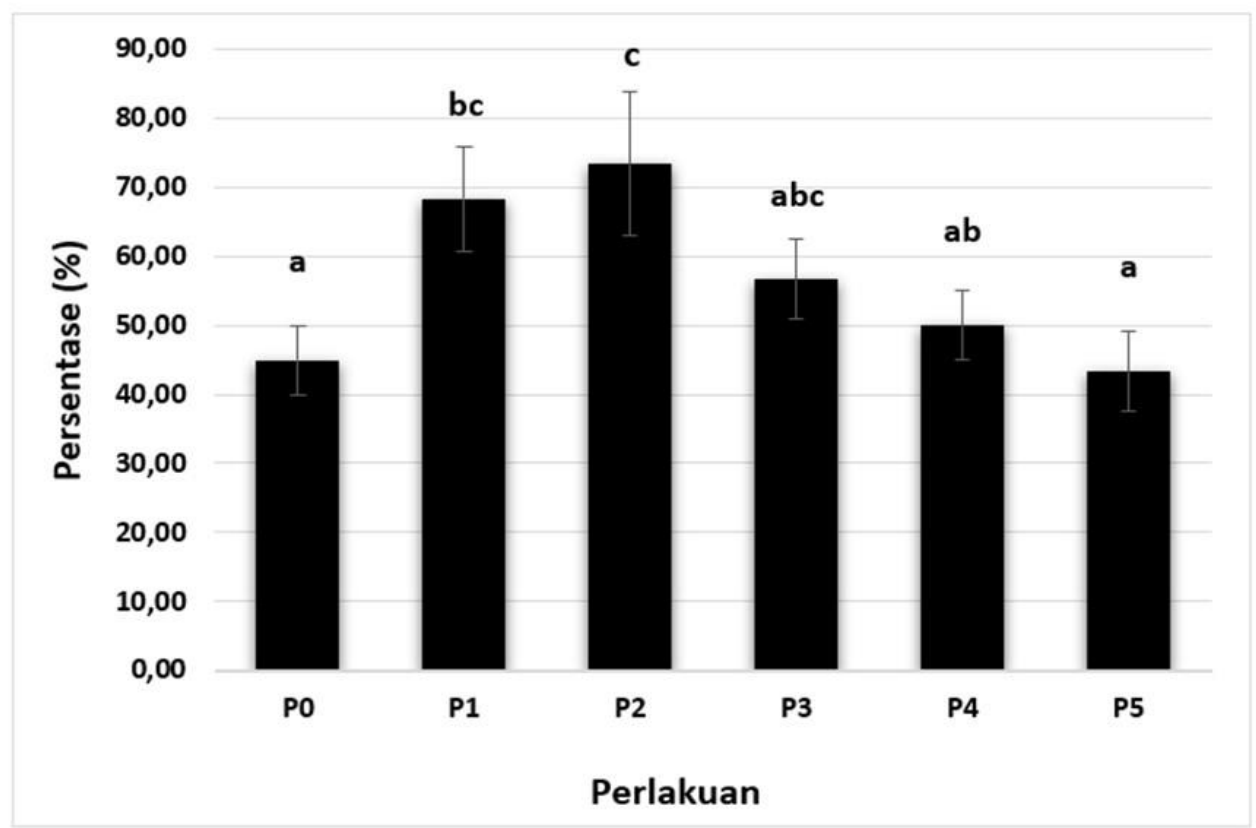

Gambar 2. Rerata Persentase Kelamin Jantan. Keterangan: P0: Kontrol, P1: Perlakuan 5 $\mathrm{mg} / \mathrm{L}$, P2: Perlakuan $10 \mathrm{mg} / \mathrm{L}, \mathrm{P} 3$ : Perlakuan $20 \mathrm{mg} / \mathrm{L}, \mathrm{P} 4$ : Perlakuan 40 mg/L, P2: Perlakuan $80 \mathrm{mg} / \mathrm{L}$. a, ab, abc, bc, c : a dan ab: Perbedaan signifikan $(\mathrm{p}<0,05)$ antara rata-rata ditentukan menggunakan ANOVA.
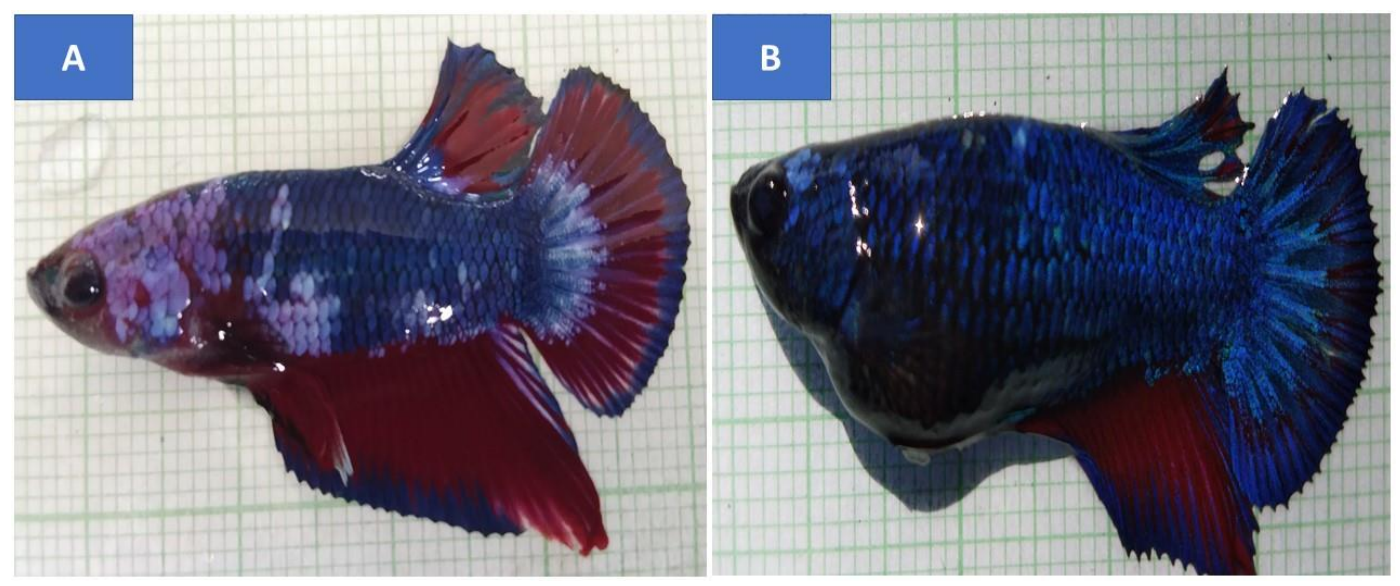

Gambar 3. Ciri Sekunder Ikan Cupang Hasil Maskulinisasi (A = Jantan, B = Betina)

Perbedaan morfologi antara ikan cupang jantan dan betina dapat dibedakan dari warnanya yang cerah dan menarik, bentuk perut ramping, serta sirip ekor dan sirip anal panjang. Sementara cupang betina berwarna kurang menarik, bentuk perut gemuk serta sirip ekor dan sirip anal pendek. Akibatnya, ikan cupang jantan memiliki nilai komersial tinggi karena sangat disukai dan diburu oleh pecinta ikan hias, sehingga akan lebih efektif dan menguntungkan bila hanya diproduksi dan dipelihara jantannya saja. Ikan jantan sangat agresif dan memiliki kebiasaan saling menyerang apabila ditempatkan dalam satu wadah (Ostrow, 1989). 


\section{Tingkat Kelangsungan Hidup Pemeliharaan}

Berdasarkan Gambar 4 diketahui bahwa persentase kelangsungan hidup larva ikan cupang pada akhir pemeliharaan adalah 63,33\% sampai $100 \%$. Berdasarkan hasil uji statistik menunjukkan bahwa tingkat kelangsungan hidup ikan cupang berbeda nyata $(\mathrm{P}<0,05)$.

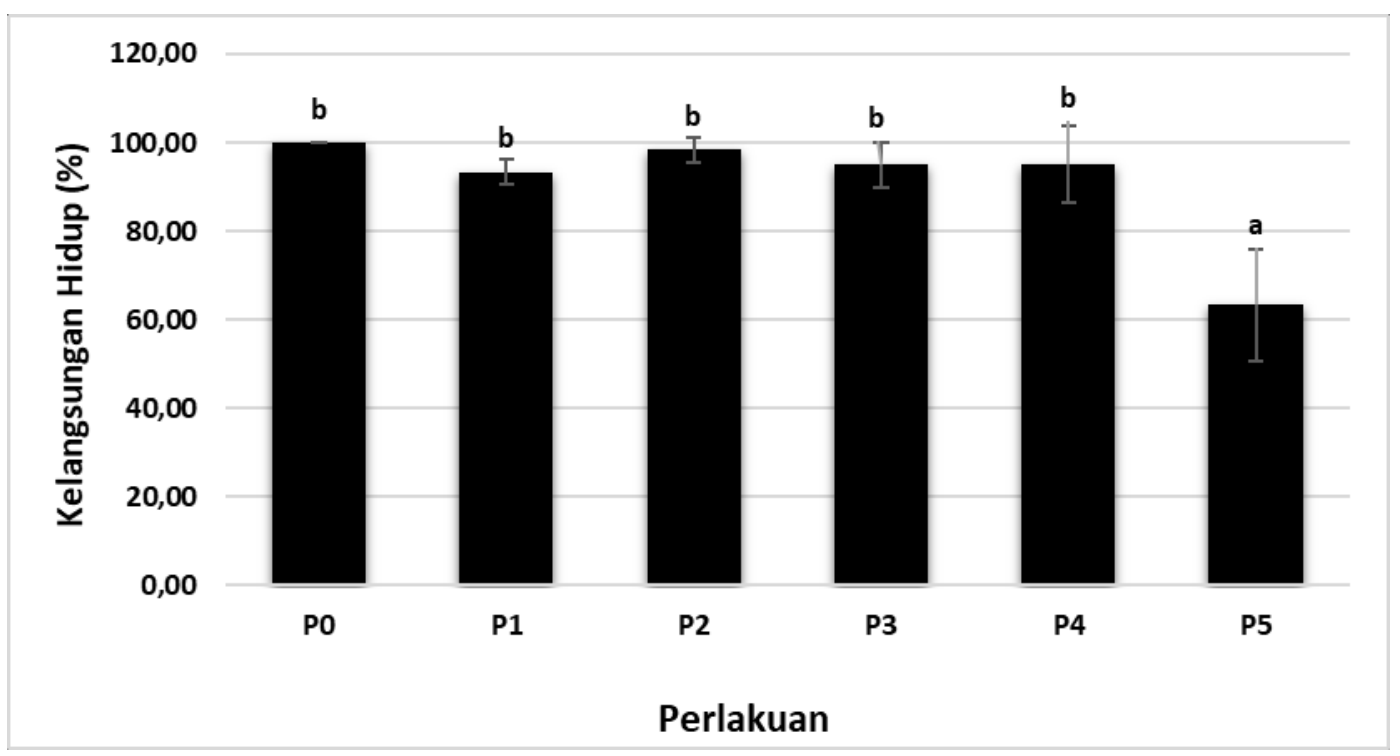

Gambar 4. Rerata Tingkat Kelangsungan Hidup Ikan Cupang. Keterangan: P0: Kontrol, P1: Perlakuan $5 \mathrm{mg} / \mathrm{L}, \mathrm{P} 2$ : Perlakuan $10 \mathrm{mg} / \mathrm{L}, \mathrm{P} 3$ : Perlakuan $20 \mathrm{mg} / \mathrm{L}, \mathrm{P} 4$ : Perlakuan $40 \mathrm{mg} / \mathrm{L}$, P2: Perlakuan $80 \mathrm{mg} / \mathrm{L}$. a, b: Perbedaan signifikan (p $<0,05)$ antara rata-rata ditentukan menggunakan ANOVA.

Rendahnya kelangsungan hidup larva ikan cupang pada salah satu perlakuan selama pemeliharaan diduga pada saat awal pemeliharaan terdapat beberapa larva ikan cupang yang mati karena larva ikan cupang yang rentan terhadap perubahan media yaitu dari media perendaman ekstrak seledri ke media pemeliharaan tanpa ekstrak seledri sehingga menyebabkan ikan stress dan menyebabkan terjadinya kematian. Kematian larva ikan cupang terjadi di hari ke-1 (pada saat ikan berumur 8 hari), di hari ke-7 (pada saat ikan berumur 14 hari) serta pada hari berikutnya hingga akhir penelitian tidak ada ikan yang mati. Selain itu kematian tertinggi pada P5 diduga bahwa pemberian konsentrasi ektrak yang tinggi.

\section{Kualitas Air}

Kualitas air merupakan faktor penting dalam budidaya ikan. Pada penelitian ini kualitas air yang diamati adalah pH, Suhu dan Oksigen Terlarut (Disolved Oxygen) yang diukur pada awal dan akhir pemeliharaan. Kualitas air yang baik adalah sesuai dengan kebutuhan biologis ikan atau masih berada dalam batas toleransi untuk ikan dapat bertahan hidup (Ukhroy, 2008). Kebutuhan ikan akan oksigen mempunyai dua aspek yaitu kebutuhan lingkungan bagi spesies tertentu dan kebutuhan konsumtif yang tergantung keadaan pada metabolism ikan (Soelistyowati et al., 2007).

Oksigen terlarut (Disolved oxygen) merupakan kandungan oksigen yang terlarut di dalam air. Oksigen terlarut menjadi salah satu factor penting yang harus diperhatikan demi 
kelangsungan hidup ikan yang dibudidaya. Kurangnya kadar oksigen terlarut dalam air akan berpengaruh negatif bagi ikan seperti stress, hypoxia, mudah terserang penyakit dan parasit bahkan dapat menyebabkan kematian massal. Rentang Data kualitas air pada pemeliharaan dapat dilihat pada Tabel 4 .

Tabel 4. Kualitas air pemeliharaan

\begin{tabular}{|c|c|c|c|}
\hline No & \multicolumn{2}{|c|}{ Parameter } & Kisaran \\
\hline 1 & Suhu $\left({ }^{\circ} \mathrm{C}\right)$ & & $\begin{array}{c}27,42- \\
28,13\end{array}$ \\
\hline 2 & $\mathrm{pH}$ & & $7,04-7,34$ \\
\hline 3 & $\begin{array}{l}\text { Oksigen } \\
\text { (mg/L) }\end{array}$ & Terlarut & $5,93-6,22$ \\
\hline
\end{tabular}

Selain penambahan ekstrak seledri, suhu merupakan salah satu faktor yang menunjang keberhasilan proses maskulinisasi ikan. Seperti yang dinyatakan oleh Arafah et al., (2013), bahwa suhu yang relatif tinggi akan mempengaruhi perkebangan gonad ikan menjadi jantan. Sebaliknya jika suhu relatif rendah maka akan berpengaruh terhadap bentuk kelamin betina pada ikan. Pada suhu yang rendah ikan akan lebih mudah terserang jamur yang dapat menyebabkan kematian pada ikan. Kenaikan suhu pada rentang 23-29 oC dapat meningkatkan populasi ikan jantan. Adapun kisaran $\mathrm{pH}$ pada penelitian ini adalah 6,93-7,36 dan masih dalam batas toleransi untuk ikan cupang daopat bertahan hidup.

Hubungan $\mathrm{pH}$ dengan kehidupan ikan sangat erat. Titik kematian ikan biasanya terjadi pada $\mathrm{pH}$ 4 atau asam dan $\mathrm{pH} 11$ atau basa. Dihabitat asalnya, ikan cupang sangat cocok berkembang dengan kondisi air yang memiliki $\mathrm{pH}$ sebesar $6.5-7.5$ (Atmadjaja dan Sitanggang, 2008). Apabiila derajat keasaman air yang akan digunakan dalam pemeliharaan ikan cupang memiliki $\mathrm{pH}$ diatas normal, para pehobi dan pembudidaya menggunakan daun ketapang untuk mencapai $\mathrm{pH}$ ideal. Ketidak idealan $\mathrm{pH}$ air yang dipakai untuk budidaya ikan cupang akan sangat berpengaruh terhadap tingkat pertumbuhan dan perkembangannya. Indikasi awal yang dapat dijadikan pedoman berkaitan dengan ketidakidealan $\mathrm{pH}$ air dapat dilihat dari tingkah laku ikan cupang diantaranya yaitu tidak memiliki nafsu makan, cara berenangnya tidak stabil, dan pertumbuhannya menjadi terhambat.

\section{KESIMPULAN}

Berdasarkan hasil penelitian dapat disimpulkan bahwa penambahan ekstrak daun seledri (A. graveolens) mampu menghasilkan presentase jenis kelamin jantan $\geq 50 \%$. Daun seledri memiliki potensi sebagai agen dalam maskulinisasi pada ikan cupang (Betta. sp).

\section{DAFTAR PUSTAKA}

Arfah H, Soelistyowati D T dan Bulkini A. 2013. Masculinization of betta fish Betta splendens by embryo immersion in extract of purwoceng Pimpinella alpina. Jurnal Akuakultur Indonesia 12 (2), 144-149.

Atmadjaja J dan Sitanggang M. (2008). Panduan Lengkap Budidaya dan Perawatan Cupang Hias. Jakarta : Agromedia .

Awaludin, dan Ridwan A. (2016). Peningkatan Survival Rate Benih Udang Windu (Peaneus Monodon) Dengan Perendaman Ekstrak Etanol Karamunting (Melastoma Malabahricum). Jurnal Harpodon Borneo, 9(1): 32-35.

Carballo J L, Inda Z H, Perez $\mathrm{P}$ dan Gravalos M D G. 2002. A Comparison Between two Brine Shrimp Assays to Detect in Vitro Cytotoxicity in Marine Natural Products. BMC Biotechnology. 2:17.

Ferdian A, Muslim dan Fitrani, M. 2017. Maskulinisasi Ikan Cupang (Betta sp.) Menggunakan Ekstrak Akar Ginseng (Panax Sp.). Jurnal 
Akuakultur Rawa Indonesia, 5(1) :1-12 (2017).

Harbone J. B. 1996. Metode fitokimia penuntun cara modern menganalisis tumbuhan. Bandung: Penerbit ITB.

Homklin S, Watanodorn T, Ong S K dan Limpiyakorn T. 2009. Biodegradation of 17 alphamethyl testosterone and isolation of MT degrading bacterium from sediment of Nile tilapia masculinization pond. Water Science and Technology 59: 261-265.

Kementerian Kelautan dan Perikanan. 2019. Laporan Indikator Kinerja Triwulan I-2019. Direktorat Jenderal Perikanan Budidaya.

Martha R D dan Zummah, A. 2018. Phytochemical Testing And Determination Of Kinetic Parameters Enzyme With Water Infusion Of Celery Extracts. Jurnal Wiyata. Vol. 5 No. 2.

Meyer B. N, Ferrigni N. R, Putnam J E, Jacobsen L B, Nichols D E, dan Mc Laughlin J L. (1982). Brine Shrimp: A Convenientgeneral bioassay for Active Plant Constituents, Planta Medica, 45: 31-34.

Ostrow M E. 1989. Betta's.T. F..H Pub. Inc. Canada. h.91.

Piferrer F. dan W. Donaldson. 1989. Gonadal differentiation in coho salmon, oncorhynchus kisutch after a single treatment with androgen at Different stages during ontogenis. J. Aquaculture. 234:229-239.

Priyono E, Muslim dan Yulisman. 2013. Masculinitation of guppy (Poecilia reticulata) by dipping pregnant guppy in honey solution with different dipping time. Jurnal Akuakultur Rawa Indonesia. 1(1): 14-22.

Putra D A. 2011. Maskulinisasi Ikan Guppy (Poecilia reticulata)
Melalui Perendaman Induk dalam Berbagai Aras Dosis Propolis. Lampung. Skripsi. Universitas Lampung.

Purwati S, Carman O, Zairin M Jr. 2004. Feminisasi Ikan Betta (Betta splendens Regan) Melalui Perendaman Embrio dalam Larutan Hormon Estradiol-17 $\beta$ dengan Dosis $400 \mu \mathrm{g} / 1$ Selama 6,12,18 dan 24 Jam. Jurnal Akuakultur Indonesia, 3(3): 9-13

Samejo M Q, Memon S, Bhanger MI dan Khan K M. 2013. Isolation and characterization of steroids from Calligonum polygonoides., J. Pharmacy Res., 6, 346-349.

Soelistyowati D T, Martatih E. dan Arfah H. 2007. Efektifitas penggunaan madu terhadap pengarahan kelamin ikan gapi (Poecilia reticulata). J. Akuakultur Indonesia. 6(2):155-160.

Sugandy dan Irawan. 2001. Budidaya Ikan Cupang Hias. Penerbit Agro Media Pustaka, Jakarta, hal 21-22.

Sumantadinata K dan Carman O. 1995. Teknologi Ginogenesis dan Seks Reversal dalam Pemuliaan Ikan. Buletin Ilmiah Gukuryoku I: 1520.

Syamsuhidayat dan Hutapea. 1991. Inventaris Tanaman Obat Indonesia, 305-306, Departemen Kesehatan Republik Indonesia, Badan Penelitian dan Pengembangan Kesehatan, Jakarta.

Ukhroy N U. 2008. Efektifitas Penggunaan Propolis Terhadap Nisbah Kelamin Ikan Guppy (Poecilia reticulata).

Zairin J R M. 2002. Sex Reversal: Memproduksi Benih Ikan Jantan atau Betina. Penebar Swadaya. Jakarta.

Zumrotun, Masyud B dan Thohari AM. 2006. Peranan sanrego Lunasia amara Blanco dalam peningkatan 
libido seksual rusa timur Cervus

Timorensis de Blainville. Media

Konservasi 11: 72-76. 
